\title{
Precise tissue bioengineering and niches of mesenchymal stem cells: Their size and hierarchy matter
}

\author{
IgOR A. KHLUSOV ${ }^{1, *}$; Larisa S. LITVINOVA ${ }^{2, *}$; Kristina A. YUROVA ${ }^{2}$; Marina Y. KHLUSOVA ${ }^{3}$ \\ 1 Department of Morphology and General Pathology, Siberian State Medical University, Tomsk, 634050, Russia \\ 2 Center for Immunology and Cell Biotechnology, Immanuel Kant Baltic Federal University, Kaliningrad, 236029, Russia \\ 3 Department of Pathophysiology, Siberian State Medical University, Tomsk, 634050, Russia
}

Key words: Mesenchymal stromal/stem cells, Natural and artificial niches, Classification, Dimension, Matrix features, Usefulness

\begin{abstract}
Stem cell microterritories (niches), as a specialized part of the extracellular matrix (ECM), are considered an important target and tool for the development of new materials, medical implants, and devices. However, tissue bioengineering products that have stem cell niches of known size on the surface or in the bulk structure of artificial materials are practically unknown. This brief review attempts to draw attention to the problematic aspects of niches as specific parts of the ECM, such as their hierarchy and size for mesenchymal stromal/stem cells (MSCs). These parameters arise directly from numerous definitions of stem cell niches as specialized morphological microterritories found in various tissues. The authors of this review analyze the known information on the hierarchy of MSC microterritories by analogy with that of hematopoietic stem cells. Occasional reports on the size of artificial MSC niches compared to natural niche candidates are summarized. A consensus on a hierarchy and optimal range of niche sizes for MSCs and other stem cells is needed to accelerate the development of prototyping technologies and additive manufacturing in applications to precise tissue bioengineering and regenerative medicine.
\end{abstract}

\section{Introduction}

According to certain estimates, the global biomaterials market will reach $\$ 47.5$ billion by 2025 , up from $\$ 35.5$ billion in 2020 . This growth is partly due to increasing funding for the development of novel biomaterials and increasing research in regenerative medicine (Biomaterials Market by Type of Materials, Application-Global Forecast to 2025, 2021).

The classical tissue engineering approach aims to design synthetic environments to direct stem cells to achieve a desired function, which can then be implanted into the organism (Seliktar, 2012; Thomas et al., 2018). Niche design is expected to provide important tools for both regenerative medicine and therapeutic discoveries (Donnelly et al., 2018; Thomas et al., 2018). Three-dimensional (3D) bioprinting technologies (rapid prototyping or additive manufacturing) and materials are being actively developed primarily to imitate the extracellular matrix (ECM) of bone, vessels, skin, cartilage, nerves and other biostructures ( $\mathrm{Gu}$ et al., 2018). Although fine resolutions (down to $10 \mu \mathrm{m}$ ) have been

${ }^{*}$ Address correspondence to: Larisa S. Litvinova,

LLitvinova@kantiana.ru; Igor A. Khlusov, khlusov63@mail.ru

Received: 24 August 2021; Accepted: 29 November 2021 achieved with 3D printing (Do et al., 2015), there are yet virtually no true tissue bioengineering products that would carry stem cell microterritories of known size on the surface or inside artificial materials.

The properties and significance of different types of mesenchymal stromal/stem cells (MSCs) and their niches for the clinical practice of regenerative medicine are being actively discussed (e.g., Han et al., 2019). However, the niches of stem cells, including hematopoietic stem cells (HSCs), owing to complicated features, have remained an enigma (Zhang et al., 2003).

There are numerous definitions and classifications of microterritories for HSCs; see, for example, the review of Khlusov et al. (2018). Numerous papers have described the properties of stem cell niches, especially HSCs, and their bioengineering in vitro and in vivo (Edalat et al., 2012; Ireland and Simmons, 2015; Abarrategi et al., 2018; Bourgine et al., 2018; Donnelly et al., 2018; Shrestha and Yoo, 2019; Zhang et al., 2019).

By analogy, MSC niches are defined as specialized, complex, multifactorial microenvironments that provide structural and functional cues that are both biochemical and biophysical. Stem cells integrate this complex set of signals with intrinsic regulatory networks to fulfill physiological 
requirements (Donnelly et al., 2018). However, stem cell niches are a small portion of the general bone marrow microenvironment (Chen, 2010).

Thus, without a clear understanding of the hierarchy and boundaries of stem cell microterritories, there is a high probability of mixing their short-range features with stimuli from the general microenvironment, as well as long-range cues of the whole body. Nevertheless, natural niches have been searched for, and artificial niches for MSCs have been created without particular understanding of the role of their classification and dimension. A search in the PubMed database (https://pubmed.ncbi.nlm.nih.gov) for the term "niche size of mesenchymal stem cells" yielded only 101 links over the past 20 years, and the term "niche size" was clearly present in the text of only 7 articles. Of course, a limited number of published studies do not reflect the interest of scientists in this topic.

Here, we provide a brief outlook on the problem of niches as specific microterritories of ECM, such as their hierarchy and dimensions for MSCs, which is urgently needed for the development of precise tissue bioengineering.

\section{A Question of MSC Niche Hierarchy}

MSC properties are suitable for tissue bioengineering and regenerative medicine, including (1) easy extraction from numerous tissues, (2) immunoregulatory capacity, (3) secretion of growth factors, and (4) the ability to differentiate into numerous target cells (Han et al., 2019). A detailed description of MSCs can be found, for instance, in Aerts and Wagemaker (2006); the minimal requirements for MSC definition are described in Dominici et al. (2006).

With the development of nanotechnology and microfluidics, the design of niches for single MSCs (Donnelly et al., 2018) has become an active area of tissue bioengineering and regenerative medicine. Niche mimicking approaches have to provide new tools to guide the behavior of a single MSC in vitro and in vivo. Such approaches could be facilitated by using biomaterials that mimic the native ECM in combination with the necessary (bio)physical and (bio)chemical cues required for stem cell control (Jahr et al., 2015). Hence, precise tissue engineering is needed to obtain detailed information about the quantitative features of niches to design bioinspired artificial matrices most similar to native structures.

The choice of material and its design features (Madsen et al., 2020), 2D and 3D tissue-like matrix (Thomas et al., 2018), and numerous complex physical (e.g., surface electric charge and free energy, temperature, fluid transport, etc.), (bio) mechanical (e.g., stiffness, shear stress, etc.), (bio)chemical (e.g., pH value, chemical groups, molecules, wettability, etc.), and topographical (shape, size, dimensions, etc.) signals affect stem cell fate and behavior (quiescence, self-renewal, differentiation, motility, and death) (Jiang and Papoutsakis, 2013; Khlusov et al., 2018).

The ECM is one of the most important structuralfunctional niche components (Chen, 2010; Assis-Ribas et al., 2018). However, the specific cues generated by a niche are currently not distinguished from those observed in the systemic microenvironment.
The stem cell niche is defined as a specific microenvironment in tissue where stem cells live in a quiescent stage but can selfrenew and differentiate in a controlled manner (Gattazzo et al., 2014). According to Lutolf and Blau (2009) and Shrestha and Yoo (2019), a stem cell in its niche can undergo four different fates: (a) quiescent, (b) symmetric divisions (giving rise to two daughter stem cells), (c) asymmetric divisions (giving rise to one daughter stem cell and one differentiated cell), and (d) divisions with loss of self-renewal (giving rise to two differentiated progeny). In other words, due to the diversity of the functional state of stem cells, there should be a complex hierarchy of their microterritories (niches), as described for hematopoietic stem cells (HSCs) (Table 1).

MSCs are closely related to HSCs and form a common niche in the bone marrow (Méndez-Ferrer et al., 2010). Therefore, a hierarchy of MSC niches cannot be excluded.

MSCs within the bone marrow stroma and cells lining compact bones in the endosteal niche have similar proliferation status and mesenchymal cell characteristics but contrasting multipotentiality (Yusop et al., 2018). Despite the purported ability of MSCs to develop approximately twelve (Aerts and Wagemaker, 2006) or even more cell lineages (Gimble et al., 2008) in vitro, the natural anatomical sites (niches) in which multipotent MSCs can reside are not defined clearly in contrast to the structuralfunctional units for HSCs. This may be due to the only 5-6 capacities (osteoblasts, chondrocytes, adipocytes, myocytes, tenocytes, and vascular smooth muscle cells/pericytes) of MSC orthodox commitment (Charbord et al., 2011; Thanabalasundaram et al., 2012) and their known plasticity (transdifferentiation capacity) (Kolf et al., 2007).

Therefore, the classifications of the potential natural and artificial niches for MSCs are almost not known in practice. For example, niches for the self-renewal and differentiation of MSCs have been proposed (Donnelly et al., 2018). Notably, the model of the functional hierarchy of stem cells, including MSCs, shows that more primitive stem cells exhibit a higher degree of intrinsic (niche independent) stemness and are more self-sufficient than committed (niche dependent) stem cells. Embryonic stem cells have a high degree of stemness and can create and modulate niches ( $\mathrm{Pal}$ and Das, 2017).

Endothelial cells (ECs) give rise to white and brown adipocytes; therefore, the vascular wall of adipose tissue capillaries may represent a regional adipogenic niche (Frontini et al., 2012). In addition, pericytic progenitors have been hypothesized to be a source of bone marrow adipocytes (Robles et al., 2019).

Matta et al. (2015) developed approaches to mimic the structure and mechanical properties of the chondrocyte niche. Moreover, Khlusov et al. (2011) proposed the existence of artificial specific microterritories (niches) in calcium phosphate material for osteogenic differentiation of MSCs and studied their properties. The possibility of transforming quiescent endosteal niches formed by MSCs and HSCs into active osteogenic MSC niches was suggested. Moreover, we later proposed their structural ("niche-relief") and functional ("niche-voltage") hierarchy to promote bone and hematopoietic engineering in vitro and in situ ectopic tests in mice (Khlusov et al., 2013a). 
TABLE 1

Summary of some morphological and functional variants of niches for hematopoietic stem cells

\begin{tabular}{ll}
\hline Niche name & References \\
\hline $\begin{array}{l}\text { Morphological (structural-functional) variants } \\
\text { Hard or soft niches }\end{array}$ & Garrett and Emerson (2009) \\
Trabecular (endosteal) or (peri)vascular niches & $\begin{array}{l}\text { Zhang et al. (2003); Calvi et al. (2003); Kiel et al. (2005); Kopp et al. } \\
(2005)\end{array}$ \\
Arteriolar or sinusoidal niches & Wei and Frenette (2018); Bello et al. (2018) \\
Hemopoietic (erythroblastic) islands & Bessis (1958); Crocker and Gordon (1985); Chasis (2006); Yu and \\
& Scadden (2016) \\
$\begin{array}{l}\text { Hematopoietic stem and progenitor cell (HSPC) vs. lymphoid } \\
\text { precursor niches }\end{array}$ & Wei and Frenette (2018) \\
$\begin{array}{l}\text { B cell vs. T cell niches } \\
\text { Megakaryocyte niche }\end{array}$ & Vionnie and Scadden (2016) \\
Functional variants & Bruns et al. (2014); Vionnie and Scadden (2016) \\
Specialized or equivalent niches & \\
Quiescent or active (activated) niches & Ugarte and Forsberg (2013) \\
\hline Note: This information may be interesting to understand a small development of the problem concerning the hierarchy of MSC niches in application to precise
\end{tabular}
tissue bioengineering.

\section{Ex Vivo Design of Synthetic Niches for MSCs. Niche Size}

Porosity and pore size are very important parameters in the development of materials for tissue engineering. 3D printing techniques are useful for designing matrices for tissue engineering, as they allow highly precise fabrication and control of the pore size, porosity, and shape (e.g., Gu et al., 2018). However, this prominent area of research (see Yang et al., 2001; Kim et al., 2017) is not considered here, as it is mainly developed in vivo (e.g., Moisenovich et al., 2012). Moreover, the bulk structure of the scaffolds has large $(>50 \mu \mathrm{m})$ pore sizes, which are preferable for multicellular ingrowth.

Macroporosity (diameter of pores $>50 \mu \mathrm{m}$ ) showed in vivo cell infiltration, bone ingrowth (osteoconductivity), and new blood vessel formation (Mastrogiacomo et al., 2006; Kim et al., 2017). In fact, new bone tissue formation can be observed in various calcium phosphate $(\mathrm{CaP})$ materials at a pore diameter of $\sim 100-800 \mu \mathrm{m}$ (Sous et al., 1998; Do et al., 2015). However, according to the dimensions, such microterritories cannot be classified as niches for single stem cells. It is possible that large pores are tissue domains for MSCs (Khlusov et al., 2018) by analogy with "regulatory volume" (domains) for HSCs (Maloney et al., 1978) due to the ingrowth of bone, bone marrow, and blood vessels.

Furthermore, we will not address the rapidly growing area of research investigating the impact of nanotopography on MSC behavior (e.g., Singh et al., 2013; Dobbenga et al., 2016), as nanoscale signaling affects cells at the subcellular level and in many ways overlaps with a separate direction called "mechanotransduction" (Ermis et al., 2018; Tortorella et al., 2021).

Finally, we deliberately did not consider the rich body of investigations devoted to the cellular and molecular regulatory components of the stem cell niche. In this regard, we refer the reader to full-text papers, for example, Scadden, 2006; Méndez-Ferrer et al., 2010; Ejtehadifar et al., 2015; Le et al., 2018; Baccin et al., 2020; Tortorella et al., 2021.
Stem cell pool size is thought to correlate with niche size. Stem cell populations are established in "niches"-specific anatomic locations (basic units) that regulate how they participate in tissue generation, maintenance and repair (Scadden, 2006). The anatomical location of a niche implies a certain microterritory that it occupies. To distinguish a niche from a systemic microenvironment, we use the concept of a niche as a natural or synthetic microterritory with a specified size. Accordingly, stem cell microterritories (niches) are discrete morphological (structural-functional) units in tissues (Crocker and Gordon, 1985; Ahmadbeigi et al., 2013; Yu and Scadden, 2016), in which "quantitative parameters of a specific microenvironment promote the qualitative control of stem cell fate" (Khlusov et al., 2018).

Therefore, stem cell niches should have a certain dimensionality that transforms absolute forces into specific forces (intensity, nominal pressure, surface loading, power, stress or distribution density, etc.) of intrinsic (e.g., ECM) and extrinsic physicochemical and biological factors affecting stem cells.

However, little is known about natural niches and how their sizes underlie the control of MSC fate (self-renewal, differentiation, and survival). In this regard, it is worth recalling that during cancellous bone remodeling in vivo, MSCs and/or preosteoblasts colonize dish-shaped sockets with a diameter and depth of $\sim 40 \mu \mathrm{m}$ caused by osteoclasts and differentiate into osteoblasts that synthesize new bone matrix (Riggs and Melton, 1995). If the geometry of these in vivo sockets is approximated as a hemisphere, the calculated base area, hemisphere area, and socket volume are $1260 \mu \mathrm{m}^{2}$, $2513 \mu \mathrm{m}^{2}$ and $10700 \mu \mathrm{m}^{3}$, respectively. Such single sockets in bone have been proposed as natural active osteogenic niches of single MSCs (see Table 2) (Khlusov et al., 2018).

It is known that the ECM is required to reconstruct niches ex vivo. The thickness of the cell-free ECM derived from the native bone marrow layer is approximately $20-100$ microns and provides a 3D environment for attachment, 
TABLE 2

Contenders for the role of natural and artificial niches for mesenchymal stem/stromal cells found in the references

\begin{tabular}{|c|c|c|c|c|c|c|c|}
\hline \multicolumn{8}{|c|}{ Natural candidates for MSC niche in vivo } \\
\hline Name & Dimensions & $\begin{array}{l}\text { Cell } \\
\text { number }\end{array}$ & Geometry & $\begin{array}{l}\text { Target } \\
\text { cells }\end{array}$ & Cell source & Cell effect & References \\
\hline \multicolumn{8}{|c|}{ Natural source for MSC niches in vitro } \\
\hline Layer & 20-100 microns thick & - & $\begin{array}{l}\text { Layer on } \\
\text { the plastic } \\
\text { surface of } \\
\text { cultural } \\
\text { plates }\end{array}$ & MSCs & $\begin{array}{l}\text { Human or mouse native cell-free ECM } \\
\text { derived from bone marrow stromal } \\
\text { cells }\end{array}$ & $\begin{array}{l}\text { Promotion } \\
\text { of proliferation and retention } \\
\text { of stem cells with a lower level } \\
\text { of reactive oxygen species } \\
\text { (ROS) compared with cells } \\
\text { cultured on uncoated plastic }\end{array}$ & $\begin{array}{l}\text { (Chen, } \\
\text { 2010) }\end{array}$ \\
\hline Material of substrate & $\begin{array}{l}\text { Microterritory } \\
\text { dimension }\end{array}$ & $\begin{array}{l}\text { Geometry } \\
\text { of } \\
\text { territories }\end{array}$ & $\begin{array}{l}\text { Factor } \\
\text { affecting } \\
\text { the cellular } \\
\text { behavior }\end{array}$ & $\begin{array}{l}\text { Cell } \\
\text { number }\end{array}$ & Cell behavior & Cell source & References \\
\hline \multicolumn{8}{|c|}{$2 \mathrm{D}$ niches in vitro } \\
\hline $\begin{array}{l}\text { Self-assembled } \\
\text { monolayers of } \\
\text { alkanethiolates }\end{array}$ & $\begin{array}{l}\text { Fibronectin }(\mathrm{FN}) \text {-coated } \\
\text { islands from } 10 \times 10 \text { to } \\
60 \times 60 \text { microns in } \\
\text { length }\end{array}$ & $\begin{array}{l}\text { Circle or } \\
\text { square }\end{array}$ & Cell shape & Single cells & $\begin{array}{l}\text { Small round islands }(\mathrm{d}=10-20 \\
\left.\text { microns; area }<314 \mu \mathrm{m}^{2}\right) \text { induced BCE } \\
\text { cell and HMVEC apoptosis. Increased } \\
\text { size of islands (from } 1590 \text { to } 4000 \mu \mathrm{m}^{2} \text { ) } \\
\text { maintained DNA synthesis } v s . \\
\text { decreased apoptosis rate. }\end{array}$ & $\begin{array}{l}\text { Bovine capillary endothelial } \\
\text { (BCE) and human } \\
\text { microvascular endothelial cells } \\
\text { (HMVECs) }\end{array}$ & $\begin{array}{l}\text { (Chen et } \\
\text { al., 1997; } \\
\text { Chen et al., } \\
\text { 1998) }\end{array}$ \\
\hline \multirow[t]{4}{*}{ Polydimethylsiloxane } & $\begin{array}{l}\text { FN "islands" (area of } \\
\sim 1204 \mu \mathrm{m}^{2} \text { ) }\end{array}$ & $\begin{array}{l}\text { Circular } \\
\text { shape }\end{array}$ & Cell shape & Single cells & $\begin{array}{l}\text { Unspread, round } \\
\text { cells differentiated into adipocytes } \\
\text { vs. osteoblasts }\end{array}$ & Human MSCs & $\begin{array}{l}\text { (McBeath } \\
\text { et al., } \\
\text { 2004) }\end{array}$ \\
\hline & $\begin{array}{l}\text { FN "islands" (area of } \\
\sim 10,000 \mu \mathrm{m}^{2} \text { ) }\end{array}$ & $\begin{array}{l}\text { Square } \\
\text { shape }\end{array}$ & Cell shape & Single cells & $\begin{array}{l}\text { Adherent and spreading cells } \\
\text { underwent osteogenesis }\end{array}$ & & \\
\hline & $\begin{array}{l}\text { FN "islands" (area of } \\
\sim 10,000 \mu \mathrm{m}^{2} \text { ) }\end{array}$ & $\begin{array}{l}\text { Square } \\
\text { shape }\end{array}$ & $\begin{array}{l}\text { Cell shape } \\
+ \text { TGF- } \beta\end{array}$ & Single cells & Cells commit into myocytes & & \\
\hline & & & & \multicolumn{4}{|c|}{$3 \mathrm{D}$ niches in vitro } \\
\hline $\begin{array}{l}\text { Photopolymerizable } \\
\text { methacrylated } \\
\text { hyaluronic acid } \\
\text { hydrogel covered by } \\
\text { poly(L-lysine)-graf t- } \\
\text { poly (ethylene } \\
\text { glycol); microwells } \\
\text { functionalized with FN }\end{array}$ & $\begin{array}{l}\text { Base area of microwells is } \\
400 \mu \mathrm{m}^{2} \text { with heights of } 9 \\
\mu \mathrm{m}\end{array}$ & $\begin{array}{l}\text { Round, } \\
\text { squared, } \\
\text { or } \\
\text { triangular } \\
\text { prism } \\
\text { shape }\end{array}$ & $\begin{array}{l}\text { Niche } \\
\text { volume } \\
\left(3600 \mu \mathrm{m}^{3}\right) \\
\text { determines } \\
\text { the cell } \\
\text { volume }\end{array}$ & $\begin{array}{l}\text { Initial } \\
\text { density of } \\
2.5 \text { cells } \\
\text { per } 1000 \\
\mu \mathrm{m}^{2} \text { of } \\
\text { area }\end{array}$ & $\begin{array}{l}\text { Cells (size of } \sim 2100 \mu \mathrm{m}^{3} ; 58 \% \text { of cell/ } \\
\text { niche volumes) were able to spread } \\
\text { optimally, leading to formation of } \\
\text { cytoskeleton fibers, gene expression } \\
\text { and metabolic activity }\end{array}$ & hMSCs & $\begin{array}{l}\text { (Bao et al., } \\
\text { 2019) }\end{array}$ \\
\hline $\begin{array}{l}\text { Microarc rough } \\
\text { calcium phosphate } \\
\text { coating on titanium } \\
\text { substrate }\end{array}$ & $\begin{array}{l}\text { Sockets with a base area } \\
>80 \mu \mathrm{m}^{2} \text { seeded by cells }\end{array}$ & $\begin{array}{l}\text { Irregular } \\
\text { concaves }\end{array}$ & $\begin{array}{l}\text { Niche size, } \\
\text { calcium } \\
\text { and } \\
\text { phosphorus }\end{array}$ & $\begin{array}{l}\text { One cell } \\
\text { per socket }\end{array}$ & $\begin{array}{l}\text { Cells preferred sockets with base areas } \\
\text { of } \sim 302(100-625) \mu \mathrm{m}^{2} \text { to differentiate } \\
\text { into osteoblasts; each cell occupied } \\
\sim 42 \% \text { of its individual socket. }\end{array}$ & $\begin{array}{l}\text { Prenatal stromal cells prepared } \\
\text { from the human lung } \\
\text { (HLPSCs) }\end{array}$ & $\begin{array}{l}\text { (Khlusov } \\
\text { et al., 2011; } \\
\text { Khlusov et } \\
\text { al., 2018) }\end{array}$ \\
\hline
\end{tabular}

growth, longevity, directional migration along the ECM fiber orientation and prolonged bone formation capacity of human and murine MSCs in vitro (Chen, 2010). Therefore, such systems may be a natural pattern for MSC niche reconstitution (Table 2).

It should be noted that the candidates for natural niches refer to bone and marrow tissues. This is not surprising since the stem cells and ECM of these tissues are the best studied. It is interesting to note that various authors refer to specialized microterritories as niches of a wide range of sizes. For instance, in the case of HSCs, niche diameter can vary widely from 1000 microns (Vodyanoy et al., 2020) and
200-300 microns (Ahmadbeigi et al., 2013) to 20-25 microns (Crocker and Gordon, 1985; Chasis, 2006; Yu and Scadden, 2016), and niches can include numerous cells. Therefore, we attempted to find scientific references addressing the in vitro design of artificial microterritories for single stem cells similar to the natural units listed in Table 2. Unfortunately, synthetic (artificial) MSC niches similar in size to natural niche candidates were rather limited.

The cell fate could be precisely controlled by the size and shape of the $2 \mathrm{D}$ and $3 \mathrm{D}$ structures fabricated using various technologies. Both the choice of material and its design specifications have a significant impact on cell functions 
(Madsen et al., 2020). Most researchers manufacture substrate topographies with predetermined dimensions to stress the cells. Cells then sense and respond to the "feature" size of nano- and micropatterns (Jiang and Papoutsakis, 2013), altering the shape (cytoskeleton), gene and metabolic activity. This in turn can determine MSC differentiation (McBeath et al., 2004; Wang et al., 2016). Convex geometries lead to adipocyte (Kilian et al., 2010) and osteoclast-like (Khlusov et al., 2013b) commitment, while concave geometries promote osteogenic lineage (Kilian et al., 2010; Khlusov et al., 2013b). Large, supermature adhesions (over 5 microns long) are thought to be required for MSC osteogenesis. Larger adhesions can transfer tensile (contractile) forces to the nucleus and increase intracellular tension (Biggs et al., 2009).

Thus, Lee et al. (2018) showed that graphene with a smaller 2D surface domain size $\left(\sim 32 \mu \mathrm{m}^{2}\right.$; irregular shape) compared to $\sim 105 \mu \mathrm{m}^{2}$ promoted the expression of mature neuronal markers in hMSCs cultured in vitro for 7 days. The authors suggested that neuronal differentiation of hMSCs is maintained by the higher density of defects at graphene domain boundaries (Lee et al., 2018). Considering an area of MSCs $>400 \mu \mathrm{m}^{2}$, these structures can be regarded as nanotopographies affecting the cytoskeleton and cell organelles.

Substrates composed of self-assembled monolayers (SAMs) of alkanethiolates containing 2D islands coated with fibronectin (FN) surrounded by nonadhesive regions were prepared by Chen et al. (1998) (Table 2). Bovine capillary endothelial (BCE) and human microvascular endothelial cells (HMVECs) were attached to islands of different sizes (from $10 \times 10$ to $60 \times 60$ microns in length) and shapes (circles or squares) to monitor cell spreading within 24 hours of culturing. Depending on the shape of the FNcoated islands, the cells formed either round or square edges. In this regard, small round islands ( $d=10-20$ microns; area $<314 \mu^{2}$ ) inhibited the proliferation of both BCE cells and HMVECs and induced cell apoptosis. As the size of islands increased (from 1590 to $4000 \mu^{2}$ ), endothelial cell growth and DNA synthesis were maintained, whereas the rate of apoptosis decreased. Thus, a switch from death to growth was observed as BCE cells and HMVECs spread on larger and larger islands, promoting cell adhesion (Chen et al., 1997, 1998).

McBeath et al. (2004) used microcontact printing on polydiaremethylsiloxane (PDMS) substrates to create small circular $\left(1024 \mu^{2}\right)$ or large square $\left(10,000 \mu \mathrm{m}^{2}\right) 2 \mathrm{D}$ "islands" of FN surrounded by regions blocked with the nonadhesive Pluronic F108. The authors concluded that hMSCs that were allowed to adhere, flatten, and spread underwent osteogenesis, whereas nonspreading round cells became adipocytes. The size of the microterritories (cell spreading area) determines the shape of proliferationarrested hMSCs and their commitment: cells plated on small islands differentiated into adipocytes after 1 week of culture, whereas on large islands, they became osteoblasts (Table 2). Furthermore, smaller micropatterns (1024 $\mu^{2}$ islands) turned MSC commitment into chondrocyte lineage, while large micropatterns $\left(10,000 \mu \mathrm{m}^{2}\right.$ islands) converted MSCs into myocytes (Gao et al., 2010).
Bao et al. $(2017,2019)$ demonstrated that a volume of the 3D microenvironment affects cell volume and gene expression more than cell shape, regardless of hydrogel stiffness. Each hMSC with a volume of $\sim 2100 \mu^{3}$ ( $\sim 16$ microns in diameter) per microwell with a volume of $3600 \mu \mathrm{m}^{3}$ (base area of $400 \mu^{2}$, Table 2) was able to optimally spread, form cytoskeletal fibers, express genes and be metabolically active. More than $60 \%$ of MSCs exhibited nuclear YAP/TAZ localization regardless of hydrogel stiffness $(5,12$, and $23 \mathrm{kPa}$ ). The nuclear translocation of Yes-associated protein and its transcriptional coactivators (YAP and TAZ) activates the osteogenic transcription factor runt-related transcription factor 2 (RUNX2). Therefore, nuclear compartmentalization of YAP/TAZ implies that MSCs commit to an osteogenic differentiation profile (Yang et al., 2014).

In another rarer in vitro approach, cells themselves "select" the in vitro synthetic microterritories with a random size distribution in the substrate, which contributes to the choice of cell fate. For example, rough calcium phosphate (CaP) coatings prepared by the microarc oxidation (MAO) technique, consisting of spherulites, valleys with small sockets and pores of different sizes, provide a biomimetic model of bone mineral ECM for MSC osteogenic differentiation (Khlusov et al., 2013b). Khlusov et al. (2011, 2018) showed that $86 \%$ of prenatal human lung stromal cells (HLPSCs) stained with alkaline phosphatase (ALP) preferred irregular sockets with areas ranging from 100 to $625 \mu \mathrm{m}^{2}$ (Table 2).

This interval corresponds to the base area of artificial microwells for single MSCs prepared by Bao et al. $(2017,2019)$. These sockets were considered microterritories (osteogenic niches), where HLPSCs differentiate and mature into osteoblasts expressing alkaline phosphatase (ALP) and osteocalcin.

It should be noted that MSCs of different pools vary greatly in diameter. Even within the same cell pool, MSCs are heterogeneous. Accordingly, the absolute size of the synthetic niche cannot be an integral indicator, but the ratio of the dimensions (volume, diameter, etc.) of the cell and the surrounding microterritory can be, as described in Bao et al. (2019). Khlusov et al. (2011) previously showed with optical and scanning electron microscopy that each HLPSC occupied $\sim 42 \%$ of the area in the individual socket of the microarc CaP coating. In addition, the SALP/SMT ratio of the total area (SALP) of cell sites with ALP-positive staining to the area (SMT) of an individual synthetic socket (microterritory, MT) occupied by a single stained cell was used to determine the osteogenic activity of the microarc CaP material in vitro (Khlusov et al., 2011, 2018). Moreover, SALP/SMT with a value of approximately $43 \%$ was optimal for promoting maximal formation of new bone/marrow systems in an ectopic test on the rough $\mathrm{CaP}$ surface implanted subcutaneously in mice (Khlusov et al., 2013a).

\section{Conclusion Remarks and Outlooks}

Currently, a comprehensive approach to solving tissue bioengineering problems is being developed through scientific trial and error, with scientists creating new composite materials and biologists conducting their ongoing studies to test their effectiveness on various cells and tissues. Most likely, such an approach is relevant to the search for 


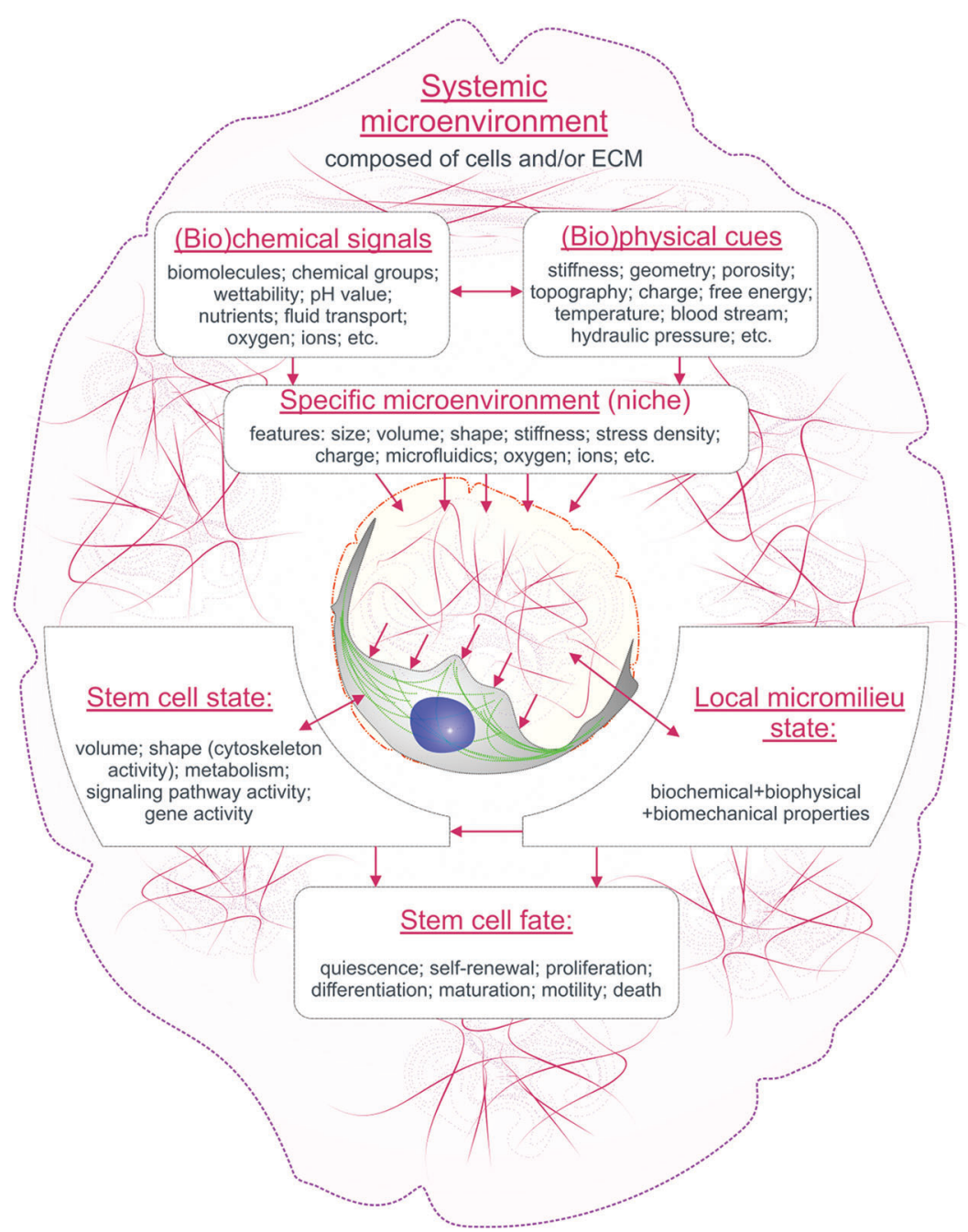

FIGURE 1. A schematic overview of the relationships between the cues of the systemic and specific microenvironment in the regulation of single MSC behavior. artificial materials and the development of technologies for their manufacture that most appropriately mimic the structure and chemistry of the natural complex ECM of various body tissues. To a first approximation, $\mathrm{CaP}$ materials resemble the ECM of bone, especially with organic filling (collagen, glycosaminoglycans, growth factors, etc.). However, the manufacture of medical devices from composite and hybrid materials raises issues of sterilization and long-term storage, which become more complicated as the chemical structure of the artificial matrix becomes more complex.

From our viewpoint, an intensive pathway based on biomimetic comparison with natural stem cell microterritories and subsequent design of artificial niches with specific dimensions is an advanced technological tool. A schematic summary of discussed cues is shown in Fig. 1.

It not only enhances biocompatibility and specific activity but also solves certain biomechanical problems of the designed implants. For example, in our experience, the presence of niche-like structures allows the thickness of the osteogenic microarc CaP coating to be significantly reduced (by approximately two times), improving its adhesive strength, which is crucial for orthopedic applications.

It seems to us that the development of truly bioinspired materials and structures for precise tissue bioengineering is on the agenda based on 1) a search for consensus on the optimal size range of microterritories for MSCs and other stem cells and their hierarchy; 2) active identification of natural niches for stem cells as specialized morphological (structural-functional) microterritories of tissues; 3 ) accurate reproduction of the structure and function of natural niches in the surface and/or bulk structure of biomimetic artificial matrices, for example, using constantly evolving prototyping and additive manufacturing techniques; and 4) preclinical and clinical trials of novel synthetic materials bearing niches for MSCs with known hierarchy, geometry and size.

Authors' Contribution: IAK conceived the work and wrote the first draft. LSL, KAY and MYK critically reviewed the draft. All authors contributed to drafting the work, revised the final manuscript, and approved submission.

Funding Statement: This research was supported by the Grants Council of the President of the Russian Federation for Leading Scientific Schools, Grant No. NSh-2495.2020.7 and Siberian State Medical University Development Program Priority 2030.

Conflicts of Interest: The authors declare that they have no conflicts of interest to report regarding the present study.

\section{References}

Abarrategi A, Mian SA, Passaro D, Rouault-Pierre K, Grey W, Bonnet D (2018). Modeling the human bone marrow niche 
in mice: From host bone marrow engraftment to bio engineering approaches. Journal of Experimental Medicine 215: 729-743. DOI 10.1084/jem.20172139.

Aerts F, Wagemaker G (2006). Mesenchymal stem cell engineering and transplantation. In: Nolta JA (ed.), Genetic Engineering of Mesenchymal Stem Cells. pp. 1-44. The Netherlands: Springer.

Ahmadbeigi N, Soleimani M, Vasei M, Gheisari Y, Mortazavi Y, Azadmanesh K, Omidkhoda A, Janzamin E, Nardi NB (2013). Isolation, characterization, and transplantation of bone marrow-derived cell components with hematopoietic stem cell niche properties. Stem Cells and Development 22: 3052-3061. DOI 10.1089/scd.2013.0005.

Assis-Ribas T, Forni MF, Winnischofer SMB, Sogayar MC, TrombettaLima M (2018). Extracellular matrix dynamics during mesenchymal stem cells differentiation. Developmental Biology 437: 63-74. DOI 10.1016/j.ydbio.2018.03.002.

Baccin C, Al-Sabah J, Velten L, Helbling PM, Grünschläger F, Hernández-Malmierca P, Nombela-Arrieta C, Steinmetz LM, Trumpp A, Haas S (2020). Combined single-cell and spatial transcriptomics reveal the molecular, cellular and spatial bone marrow niche organization. Nature Cell Biology 22: 38-48. DOI 10.1038/s41556-019-0439-6.

Bao M, Xie J, Piruska A, Huck WT (2017). 3D microniches reveal the importance of cell size and shape. Nature Communications 8: 1075. DOI 10.1038/s41467-017-02163-2.

Bao M, Xie J, Katoele N, Hu X, Wang B, Piruska A, Huck WTS (2019). Cellular volume and matrix stiffness direct stem cell behavior in a 3D microniche. ACS Applied Materials \& Interfaces 11: 1754-1759. DOI 10.1021/acsami.8b19396.

Bello AB, Park H, Lee SH (2018). Current approaches in biomaterialbased hematopoietic stem cell niches. Acta Biomaterialia 72: 1-15. DOI 10.1016/j.actbio.2018.03.028.

Bessis M (1958). L'iloterythroblastique, unite fonctionelle de la moelleosseuse (Erythroblastic island, functional unity of bone marrow). Revue d'hematologie 13: 8-11.

Biggs MJP, Richards RG, Gadegaard N, Wilkinson CDW, Oreffo ROC, Dalby MJ (2009). The use of nanoscale topography to modulate the dynamics of adhesion formation in primary osteoblasts and ERK/MAPK signalling in STRO-1+ enriched skeletal stem cells. Biomaterials 30: 5094-5103. DOI 10.1016/j.biomaterials.2009.05.049.

Biomaterials Market by Type of Materials, Application-Global Forecast to 2025 (2021). Report ID 4604339, 299. https:// www.reportbuyer.com/product/4604339/biomaterials-marketby-type-of-materials-application-global-forecast-to-2025. html.

Bourgine PE, Klein T, Paczulla AM, Shimizu T, Kunz L et al. (2018). In vitro biomimetic engineering of a human hematopoietic niche with functional properties. Proceedings of the National Academy of Sciences of the United States of America 115: 5688-5695. DOI 10.1073/pnas.1805440115.

Bruns I, Lucas D, Pinho S, Ahmed J, Lambert MP et al. (2014). Megakaryocytes regulate hematopoietic stem cell quiescence through CXCL4 secretion. Nature Medicine 20: 1315-1320. DOI 10.1038/nm.3707.

Calvi LM, Adams GB, Weibrecht KW, Weber JM, Olson DP et al. (2003). Osteoblastic cells regulate the haematopoietic stem cell niche. Nature 425: 841-846. DOI 10.1038/nature02040.

Charbord P, Livne E, Gross G, Häupl T, Neves NM, Marie P, Bianco P, Jorgensen C (2011). Human bone marrow mesenchymal stem cells: A systematic reappraisal via the genostem experience. Stem Cell Reviews and Reports 7: 32-42. DOI 10.1007/s12015-010-9125-6.

Chasis JA (2006). Erythroblastic islands: Specialized microenvironmental niches for erythropoiesis. Current Opinion in Hematology 13: 137-141. DOI 10.1097/01.moh.0000219657.57915.30.

Chen CS, Mrksich M, Huang S, Whitesides GM, Ingber DE (1997). Geometric control of cell life and death. Science 276: 14251428. DOI 10.1126/science.276.5317.1425.

Chen XD (2010). Extracellular matrix provides an optimal niche for the maintenance and propagation of mesenchymal stem cells. Birth Defects Research (Part C) 90: 45-54. DOI 10.1002/ bdrc.20171.

Chen CS, Mrksich M, Huang S, Whitesides GM, Ingber DE (1998). Micropatterned surfaces for control of cell shape, position, and function. Biotechnology Progress 14: 356-363. DOI $10.1021 / \mathrm{bp} 980031 \mathrm{~m}$.

Crocker PR, Gordon S (1985). Isolation and characterization of resident stromal macrophages and hematopoietic cell clusters from mouse bone marrow. Journal of Experimental Medicine 162: 993-1014. DOI 10.1084/jem.162.3.993.

Do AV, Khorsand B, Geary SM, Salem AK (2015). 3D printing of scaffolds for tissue regeneration applications. Advanced Healthcare Materials 4: 1742-1762. DOI 10.1002/ adhm.201500168.

Dobbenga S, Fratila-Apachitei LE, Zadpoor AA (2016). Nanopatterninduced osteogenic differentiation of stem cells-A systematic review. Acta Biomaterialia 46: 3-14. DOI 10.1016/j. actbio.2016.09.031.

Dominici M, Le Blanc K, Mueller I, Slaper-Cortenbach I, Marini F, Krause D, Deans R, Keating A, Prockop DJ, Horwitz E (2006). Minimal criteria for defining multipotent mesenchymal stromal cells. The International Society for Cellular Therapy position statement. Cytotherapy 8: 315317. DOI 10.1080/14653240600855905.

Donnelly H, Salmeron-Sanchez M, Dalby MJ (2018). Designing stem cell niches for differentiation and self-renewal. Journal of the Royal Society Interface 15: 20180388. DOI 10.1098/rsif.2018.0388.

Edalat F, Bae H, Manoucheri S, Cha JM, Khademhosseini A (2012). Engineering approaches toward deconstructing and controlling the stem cell environment. Annals of Biomedical Engineering 40: 1301-1315. DOI 10.1007/s10439-011-0452-9.

Ejtehadifar M, Shamsasenjan K, Movassaghpour A, Akbarzadehlaleh P, Dehdilani N, Abbasi P, Molaeipour Z, Saleh M (2015). The effect of hypoxia on mesenchymal stem cell biology. Advanced Pharmaceutical Bulletin 5: 141-149. DOI 10.15171/apb.2015.021.

Ermis M, Antmen E, Hasirci V (2018). Micro and nanofabrication methods to control cell-substrate interactions and cell behavior: A review from the tissue engineering perspective. Bioactive Materials 6: 1789-1790. DOI 10.1016/j.bioactmat.2018.05.005. 2020.

Frontini A, Giordano A, Cinti S (2012). Endothelial cells of adipose tissues: A niche of adipogenesis. Cell Cycle 11: 2765-2766. DOI $10.4161 / \mathrm{cc} .21255$.

Gao L, McBeath R, Chen CS (2010). Stem cell shape regulates a chondrogenic vs. myogenic fate through Racl and $\mathrm{N}$ cadherin. Stem Cells 28: 564-572. DOI 10.1002/stem.308.

Garrett RW, Emerson SG (2009). Bone and blood vessels: The hard and the soft of hematopoietic stem cell niches. Cell Stem Cell 4: 503-506. DOI 10.1016/j.stem.2009.05.011.

Gattazzo F, Urciuolo A, Bonaldo P (2014). Extracellular matrix: A dynamic microenvironment for stem cell niche. Biochimica and Biophysica Acta-Biomembranes 1840: 2506-2519. DOI 10.1016/j.bbagen.2014.01.010. 
Gimble JM, Guilak F, Nuttall ME, Sathishkumar S, Vidal M, Bunnell BA (2008). In vitro differentiation potential of mesenchymal stem cells. Transfusion Medicine and Hemotherapy 35: 228238. DOI 10.1159/000124281.

Gu BK, Choi DJ, Park SJ, Kim YJ, Kim CH (2018). 3D bioprinting technologies for tissue engineering applications. Advances in Experimental Medicine and Biology 1078: 15-28. DOI 10.1007/978-981-13-0950-2.

Han Y, Li X, Zhang Y, Han Y, Chang F, Ding J (2019). Mesenchymal stem cells for regenerative medicine. Cells 8: 886. DOI $10.3390 /$ cells 8080886 .

Ireland RG, Simmons CA (2015). Human pluripotent stem cell mechanobiology: Manipulating the biophysical vicroenvironment for regenerative medicine and tissue engineering applications. Stem Cells 33: 3187-3196. DOI 10.1002/stem.2105.

Jahr H, Matta C, Mobasheri A (2015). Physicochemical and biomechanical stimuli in cellbased articular cartilage repair. Current Rheumatology Reports 17: 22. DOI 10.1007/s11926014-0493-9.

Jiang J, Papoutsakis ET (2013). Stem-cell niche based comparative analysis of chemical and nano-mechanical material properties impacting ex vivo expansion and differentiation of hematopoietic and mesenchymal stem cells. Advanced Healthcare Materials 2: 25-42. DOI 10.1002/adhm.201200169.

Khlusov IA, Khlusova MY, Zaitsev KV, Kolokol'tsova TD, Sharkeev YP, Pichugin VF, Legostaeva EV, Trofimova IE, Klimov AS, Zhdanova AI (2011). Pilot in vitro study of the parameters of artificial niche for osteogenic differentiation of human stromal stem cell pool. Bulletin Experimental Biology and Medicine 150: 535-542. DOI 10.1007/s10517-011-1184-4.

Khlusov IA, Dekhtyar Y, Khlusova MY, Gostischev EA, Sharkeev YP, Pichugin VF, Legostaeva EV (2013a). Novel concepts of nicherelief and niche-voltage for stem cells as a base of bone and hematopoietic tissues biomimetic engineering. The International Federation for Medical and Biological Engineering Proceedings 38: 99-102. DOI 10.1007/978-3-642-34197-7_26.

Khlusov IA, Shevtsova NM, Khlusova MY (2013b). Detection in vitro and quantitative estimation of artificial microterritories which promote osteogenic differentiation and maturation of stromal stem cells. Methods in Molecular Biology 1035: 103-119. DOI 10.1007/978-1-62703-508-8.

Khlusov IA, Litvinova LS, Khlusova MY, Yurova KA (2018). Concept of hematopoietic and stromal niches for cell-based diagnostics and regenerative medicine (a review). Current Pharmaceutical Design 24: 3034-3054. DOI 10.2174/ 1381612824666180829154119.

Kiel MJ, Yilmaz OH, Iwashita T, Yilmaz OH, Terhorst C, Morrison SJ (2005). SLAM family receptors distinguish hematopoietic stem and progenitor cells and reveal endothelial niches for stem cells. Cell 121: 1109-1121. DOI 10.1016/j.cell.2005.05.026.

Kilian KA, Bugarija B, Lahn BT, Mrksich M (2010). Geometric cues for directing the differentiation of mesenchymal stem cells. Proceedings of the National Academy of Sciences of the United States of America 107: 4872-4877. DOI 10.1073/pnas.0903269107.

Kim HD, Amirthalingam S, Kim SL, Lee SS, Rangasamy J, Hwang NS (2017). Biomimetic materials and fabrication approaches for bone tissue engineering. Advanced Healthcare Materials 6: 1700612. DOI 10.1002/adhm.201700612.

Kolf CM, Cho E, Tuan RS (2007). Mesenchymal stromal cells. Biology of adult mesenchymal stem cells: Regulation of niche, self-renewal and differentiation. Arthritis Research \& Therapy 9: 204-219. DOI 10.1186/ar2116.
Kopp HG, Avecilla ST, Hooper AT, Rafii S (2005). The bone marrow vascular niche: Home of HSC differentiation and mobilization. Physiology (Bethesda) 20: 349-356. DOI 10.1152/physiol.00025.2005.

Le PM, Andreeff M, Battula VL (2018). Osteogenic niche in the regulation of normal hematopoiesis and leukemogenesis. Haematologica 103: 1945-1955. DOI 10.3324/haematol.2018.197004.

Lee YJ, Seo TH, Lee S, Jang W, Kim MJ, Sung JS (2018). Neuronal differentiation of human mesenchymal stem cells in response to the domain size of graphene substrates. Journal of Biomedical Materials Research Part A 106: 43-51. DOI 10.1002/jbm.a.36215.

Lutolf MP, Blau HM (2009). Artificial stem cell niches. Advanced Materials 21: 3255-3268. DOI 10.1002/adma.200802582.

Madsen E, Mededovic M, Kohn DH (2020). Review on material parameters to enhance bone cell function in vitro and in vivo. Biochemical Society Transactions 8: 2039-2050. DOI 10.1042/BST20200210.

Maloney MA, Dorie MJ, Lamela RA, Rogers ZR, Patt HM (1978). Hematopoietic stem cell regulatory volumes as revealed in studies of the bgj/bgj:W/WV chimera. Journal of Experimental Medicine 147: 1189-1197. DOI 10.1084/jem.147.4.1189.

Mastrogiacomo M, Scaglione S, Martinetti R, Dolcini L, Beltrame F, Cancedda R, Quarto R (2006). Role of scaffold internal structure on in vivo bone formation in macroporous calcium phosphate bioceramics. Biomaterials 27: 3230 3237. DOI 10.1016/j.biomaterials.2006.01.031.

Matta C, Khademhosseini A, Mobasheri A (2015). Mesenchymal stem cells and their potential for microengineering the chondrocyte niche. EBioMedicine 2: 1560-1561. DOI 10.1016/j.ebiom.2015.10.015.

McBeath R, Pirone DM, Nelson CM, Bhadriraju K, Chen CS (2004). Cell shape, cytoskeletal tension, and RhoA regulate stem cell lineage commitment. Developmental Cell 6: 483-495. DOI 10.1016/S1534-5807(04)00075-9.

Méndez-Ferrer S, Michurina TV, Ferraro F, Mazloom AR, Macarthur BD, Lira SA, Scadden DT, Ma'ayan A, Enikolopov GN, Frenette PS (2010). Mesenchymal and haematopoietic stem cells form a unique bone marrow niche. Nature 466: 829834. DOI 10.1038/nature09262.

Moisenovich MM, Pustovalova O, Shackelford J, Vasiljeva TV, Druzhinina TV et al. (2012). Tissue regeneration in vivo within recombinant spidroin 1 scaffolds. Biomaterials 33: 3887-3898. DOI 10.1016/j.biomaterials.2012.02.013.

Pal B, Das B (2017). In vitro culture of naïve human bone marrow mesenchymal stem cells: A stemness based approach. Frontiers in Cell and Developmental Biology 5: 69. DOI 10.3389/fcell.2017.00069.

Riggs BL, Melton LJ III (1995). Osteoporosis: Etiology, Diagnosis, and Management. (2nd ed.), pp. 524. Philadelphia, USA: Lippincott-Raven.

Robles H, Park S, Joens MS, Fitzpatrick JAJ, Craft CS, Scheller EL (2019). Characterization of the bone marrow adipocyte niche with three-dimensional electron microscopy. Bone 118: 89-98. DOI 10.1016/j.bone.2018.01.020.

Scadden DT (2006). The stem-cell niche as an entity of action. Nature 441: 1075-1079. DOI 10.1038/nature04957.

Seliktar D (2012). Designing cell-compatible hydrogels for biomedical applications. Science 336: 1124-1128. DOI 10.1126/science.1214804.

Shrestha KR, Yoo SY (2019). Phage-based artificial Niche: The recent progress and future opportunities in stem cell therapy. Stem Cells International 2019: 1-14. DOI 10.1155/2019/4038560. 
Singh AV, Patil R, Thombre DK, Gade WN (2013). Micronanopatterning as tool to study the role of physicochemical properties on cell-surface interactions. Journal of Biomedical Materials Research Part A 101: 3019-3032. DOI 10.1002/jbm.a.34586.

Sous M, Bareille R, Rouais F, Clément D, Amédée J, Dupuy B, Baquey C (1998). Cellular biocompatibility and resistance to compression of macroporous beta-tricalcium phosphate ceramics. Biomaterials 19: 2147-2153. DOI 10.1016/S01429612(98)00118-5.

Thanabalasundaram G, Arumalla N, Tailor HD, Khan WS (2012). Regulation of differentiation of mesenchymal stem cells into musculoskeletal cells. Current Stem Cell Research \& Therapy 7: 95-102. DOI 10.2174/157488812799218974.

Thomas D, O'Brien T, Pandit A (2018). Toward customized extracellular Niche engineering: Progress in cell-entrapment technologies. Advanced Materials 30: 1703948. DOI 10.1002/adma.201703948.

Tortorella I, Argentati C, Emiliani C, Martino S, Morena F (2021). The role of physical cues in the development of stem cellderived organoids. European Biophysics Journal 73: 71. DOI 10.1007/s00249-021-01551-3.

Ugarte F, Forsberg EC (2013). Haematopoietic stem cell niches: New insights inspire new questions. EMBO Journal 32: 25352547. DOI 10.1038/emboj.2013.201.

Vionnie WCY, Scadden DT (2016). Heterogeneity of the bone marrow niche. Current Opinion in Hematology 23: 331338. DOI 10.1097/MOH.0000000000000265.

Vodyanoy V, Pustovyy O, Globa L, Kulesza RJ Jr, Sorokulova I (2020). Hemmule: A novel structure with the properties of the stem cell niche. International Journal of Molecular Sciences 21: 539. DOI 10.3390/ijms21020539.
Wang X, Nakamoto T, Dulińska-Molak I, Kawazoe N, Chen G (2016). Regulating the stemness of mesenchymal stem cells by tuning micropattern features. Journal of Materials Chemistry 4: 37-45. DOI 10.1039/C5TB02215K.

Wei Q, Frenette PS (2018). Niches for hematopoietic stem cells and their progeny. Immunity 48: 632-648. DOI $10.1016 / \mathrm{j}$. immuni.2018.03.024.

Yang C, Tibbitt MW, Basta L, Anseth KS (2014). Mechanical memory and dosing influence stem cell fate. Nature Materials 13: 645-652. DOI 10.1038/nmat3889.

Yang S, Leong KF, Du Z, Chua CK (2001). The design of scaffolds for use in tissue engineering. Part I. Traditional factors. Tissue Engineering 7: 679-689. DOI 10.1089/107632701753337645.

Yin T, Li L (2006). The stem cell niches in bone. Journal of Clinical Investigation 116: 1195-1201. DOI 10.1172/JCI28568.

Yu VW, Scadden DT (2016). Heterogeneity of the bone marrow niche. Current Opinion in Hematology 23: 331-338. DOI 10.1097/MOH.0000000000000265.

Yusop N, Battersby P, Alraies A, Sloan AJ, Moseley R et al. (2018). Isolation and characterisation of mesenchymalstem cells from rat bone marrow and the endosteal niche: A comparative study. Stem Cells International 2018: 6869128. DOI 10.1155/2018/6869128.

Zhang J, Niu C, Ye L, Huang H, He X et al. (2003). Identification of the haematopoietic stem cell niche and control of the niche size. Nature 425: 836-841. DOI 10.1038/nature02041.

Zhang P, Zhang C, Li J, Han J, Liu X, Yang H (2019). The physical microenvironment of hematopoietic stem cells and its emerging roles in engineering applications. Stem Cell Research \& Therapy 10: 327. DOI 10.1186/s13287-019-1422-7. 